\title{
PREDICTING ORGANIZATIONAL CITIZENSHIP BEHAVIOR THROUGH PSYCHOLOGICAL OWNERSHIP AND JOB SATISFACTION IN FOUR-STAR HOTELS
}

\author{
I Gusti Ayu Manuati DEWI* \\ Udayana University, Faculty of Economics and Business, Indonesia, e-mail: learning_ya@unud.ac.id \\ I Gede RIANA \\ Udayana University, Faculty of Economics and Business, Indonesia, e-mail: gederiana@unud.ac.id
}

Jati KASUMA

Universiti Teknologi Mara Sarawak, Faculty of Business and Management, Malaysia, e-mail: jati@uitm.edu.my

Erin MCGUINNESS

Pace University, Lubin School of Business, New York City, USA, e-mail: em97784n@pace.edu

Siti MARIA

Faculty of Economics and Business, Department of Management, Indonesia, e-mail: siti.maria@ feb.unmul.ac.id

Dio Caisar DARMA

Department of Management, Samarinda High School of Economics, Indonesia e-mail: diocaisar@stiesam.ac.id

\begin{abstract}
Citation: Dewi, I.G.A.M., Riana, I.G., Kasuma, J., Mcguinness, E., Maria, S., \& Darma, D.C. (2021). PREDICTING ORGANIZATIONAL CITIZENSHIP BEHAVIOR THROUGH PSYCHOLOGICAL OWNERSHIP AND JOB SATISFACTION IN FOUR-STAR HOTELS. GeoJournal of Tourism and Geosites, 37(3), 807-813. https://doi.org/10.30892/gtg.37310-712
\end{abstract}

\begin{abstract}
This study examines the relationship between Psychological Ownership (PO) on Job Satisfaction (JS) and Organizational Citizenship behaviour (OCB). Using 240 front-line samples from five-star hotel workers, these studies are quantitatively planned. Empirical data were collected from employees via a questionnaire and analysed using Partial Least Square (PLS). The results indicate that Psychological Ownership and Job Satisfaction enhance the Organizational Citizenship behaviour, but the Psychological Ownership has a stronger impact. This result also provides evidence that there is a disparity in control between the employee's personality and their attitude toward their actions at the workplace. The findings of this article can provide insights to improve the Organizational Citizenship behaviour of employees, and that management must pay attention to personalities of employees, as personality traits of workers appear to influence Organizational Citizenship behaviour. This study examined the attitude effect (JS) and personality traits (PO) against OCB. Theoretically, some previous studies suggest that the predictors of OCB are JS and organizational engagement as indicators of the attitudes of the employees. Thus, this study would investigate JS, PO and OCB at well-known hotels in Bali, Indonesia.
\end{abstract}

Key words: psychological ownership, job satisfaction, organizational citizenship behaviour

\section{INTRODUCTION}

One of the prominent hospitality industries contributing to national economic growth is the tourism industry, specifically the hotel industry (Tsai and Wu, 2010; Darma et al., 2020; Akter et al., 2020; Rahmawati et al., 2021). Economic growth notwithstanding, the industry has a reputation for inadequate working conditions in the hospitality sector (e.g. Arusteu, 2013; Kamri et al., 2020; Ratnasari et al., 2020), as evidenced by the comparatively limited efforts made by organizations to improve poor working conditions and the quality of human resources (Suharto et al., 2019). Hallin and Marnburg (2008) noted that employees play a significant role in increasing customer satisfaction and loyalty. Therefore, the organisation need the creative employee to create higher creativity of employees in the workplace (Riana et al., 2020). Another study applying descriptive resource-based view theory (Barney, 1991) indicated that human resource management is one of the most precious and scarce of all company assets. Successful organizations often encourage their employees to work beyond their primary tasks (Robbins and Judge, 2015). The work contributions of employees that go beyond their formal job description duties are known as OCB (Podsakoff et al., 2000; Smith et al., 1983). The concept of OCB has become important for research into organizational behaviour (Asha and Jyothi, 2013). OCB is described as a form of work behaviour with various aspects of work attitudes as the key predictors of enhancing work behaviour (Podsakoff et al., 2000; Smith et al., 1983) and greater organizational performance (Podsakoff et al., 2000; Organ and Ryan, 1995; Podsakoff et al., 2009) by hiring the best staff (Podsakoff et al., 2003). There are a number of factors that can form OCB, and one of the main deciding factors is work satisfaction (Zhao et al., 2014). Satisfied workers are more likely to speak favorably about the company (Afaq et al., 2017), support their colleagues, and perform beyond usual standards (Foote and Li-Ping Tang, 2008; Noermijati and Primasari, 2015; Zheng et al., 2014: Riana, 2018).

\footnotetext{
* Corresponding author
} 
They may therefore be more cooperative when duty calls because they want to repeat these positive experiences (Aftab, 2012; Khalid et al., 2011) and demonstrate their good interpersonal skills (Chiaburu et al., 2011). This behavior reflects OCB, a concept that is not mentioned in formal job descriptions but is highly valuable as it increases the efficiency of the organization (Katz, 1964; Sloat, 1999). Moreover, it is crucial for management to satisfy employees by continuously maintaining internal relations, the compensation system and the work itself (Ileri and Soylu, 2012). A number of researchers (Samancioglu et al., 2020; Agrawal and Gautam, 2020; Yoon and Suh, 2003) have shown that JS has a significant impact on OCB. Kumar et al. (2009) point out that there is increasing evidence that OCB is significantly influential and capable of improving individual, team, and organizational performance. Foote and Li-Ping Tang (2008) emphasized that JS contributes significantly to the cultivation of OCB among employees. Many researchers (Choi et al., 2019; Zeinabadi, 2010; Foote and Li Ping Tang, 2008) argue that JS is a dominant factor directly affecting the level of OCB demonstrated by employees. In addition to JS, psychological ownership (PO) is one of the factors that cultivate OCB among employees (Ramos et al., 2014). Employees can develop positive, negative or even mixed feelings about behaviour through PO (Pierce et al., 2001).

Van Dyne and Pierce (2004) stated that PO is an individual psychological condition that generates a possessive attachment to a specific target. Bambale (2013) presents the possibility that psychological possession is one of OCB's primary determinants. Scholars have found that the more severe the organizations' possessive connection, the higher the JS level (Van Dyne and Pierce, 2004; Mustafa et al., 2016; Pierce et al., 2001). Strong PO motivates employees to accept a positive, personal or impersonal feeling towards their properties. As a form of job behaviour, assumptions have been developed in the current study to contribute to the role of a job attitude as a key predictor in the analysis. There are two employment-related attitudes that are predicted to affect OCB of employees, including: PO (Van Dyne and Pierce, 2004; Ramos et al., 2014) and JS (Cohen and Vigoda, 2000; Van Dyne and Pierce, 2004; Cohen and Vigoda, 2000; Yoon and Suh, 2003). Similarly, the aim of this study is to analyse the prediction of OCB through PO and JS in four-star hotels. One recommendation by Van Dyne and Pierce (2004) was to research the effect of PO on employee behaviour in non-Western settings. The current study attempts to fill that gap in extant literature. Additionally, the study builds upon extant literature by examining the concepts of OCB and PO within the realm of service-based business, and more specifically, the hotel industry.

\section{LITERATURE REVIEW}

PO is a manifestation of a psychological sense of ownership of the organization (Van Dyne and Pierce, 2004). Psychological feelings of ownership of the object do not depend on whether the subjects consider themselves to be the legal owner of the object; they can be claimed by employees who, even in the form of stock, have no ownership of the company at all, yet feel as though they take a small part of ownership. Such ownership emotions may motivate employees to behave positively, develop self-efficacy and strengthen their sense of obligation towards the organization. Their sense of ownership within the organization, including creating OCB, has a beneficial influence on the organization (Van Dyne and Pierce, 2004; Ramos et al., 2014). Research by Van Dyne and Pierce (2004) shows that PO or feelings of ownership towards the company psychologically motivates workers to do more than the standard job requirements demand as part of their work (Mustafa et al., 2015; Pan et al., 2014). Based on these concepts; we propose the following:

\section{Hypothesis 1: Psychological Ownership has a significant influence on OCB}

The Pay (compensation) element refers to the pay workers earn. It is assumed to be within reasonable levels of fairness and equitability among the organization's colleagues. Regarding the advancement of workers, there is an assumed equal probability that workers will be able to improve their expertise in different fields, thus creating equal opportunity for upward mobility in the organization. The supervisor's position and oversight provide workers the support and technical assistance they need. Eventually, JS also contributes to the co-worker atmosphere (Nurak and Riana, 2017). The collaborators play a role in providing task-related social and technical support. A high level of JS can affect the efficiency and effort of the employees to demonstrate OCB (Cohen and Vigoda, 2000; Van Dyne and Pierce, 2004). Extant research found that JS and OCB influence each other (Asha and Jyothi, 2013; Kim, 2006; Mushtaq et al., 2014; Shokrkon and Naami, 2008). In fact, some studies found that JS affects OCB significantly (Mohammad et al., 2011; Murphy et al., 2002). Asha and Jyothi (2013) found a reciprocal relationship between internal branding activities and OCB. That is, employee satisfaction and commitment to the organization leads to OCB and vice versa. Based on these strong arguments, we propose:

Hypothesis 2: JS has a significant influence on OCB.

Pierce et al. (2001) suggest that PO, manifested by the instinctive sense of ownership, stems from three key human motivators. First is efficacy. The sense of ownership, the desire to possess is an intrinsic condition that is part of every human being. Possession provides for satisfaction and control. Second, individuals establish a sense of self-identity by possessing material and non-material symbols that identify and reflect the self. Third, people need to have a place. This territorial ownership of space facilitates the feeling of home and is a human need. Combined, these three determinants have major implications for behaviour, emotions and psychology. A strong sense of psychological ownership will influence the behaviour of employees to undertake tasks that are not part of their primary tasks and functions. Studies indicate the correlation between PO and JS (Van Dyne and Pierce, 2004; Vandewalle et al.,1995). Ownership feelings have been shown to increase job satisfaction, as well as promote an atmosphere where JS grows (Van Dyne and Pierce, 2004; Klein and Kozlowski, 2000; Pierce et al., 2004). In addition, happy workers appear to take on more than their position demands (Kim, 2006; Murphy et al., 2002; Mushtaq et al., 2014; Shokrkon and Naami, 2008). Therefore, we propose:

Hypothesis 3. Psychological Ownership has a significant influence on JS. 


\section{RESEARCH METHODOLOGY}

The population of this study is from four-star hotels in Bali. More specifically, the sample includes four-star hotels in Kuta and Legian-Bali. This study is quantitative using data collected through the distribution of questionnaires to staff in the housekeeping and front office departments. There was a total of 350 questionnaires distributed. A total of 255 questionnaires were collected and, after analysis, only 240 were considered valid for analysis. The questionnaire consists of five optional answers with points ranging from 1 to 5, which are strongly disagreed (1), disagreed (2), neutral (3), agreed (4) and strongly agreed (5). The questionnaire contains three variables, namely psychological ownership (PO) adopted by Van Dyne and Pierce (2004), JS adapted from research by Spector (1985), and Hakim and Sutrisno (2018), and OCB adapted from research by Podsakoff et al. (2000) and Organ (1997). These researchers apply Partial Least Square (PLS3) to examine the hypotheses. The profiles of respondents were collected from 240 employees of housekeeping and front office departments. Most of the employees in the front office and housekeeping who responded were men-149 respondents $(62.08 \%)$ - and 91 respondents (37.92\%) were women. The majority of the respondents (118 or 49.16\%) were 21-30 years old, and the age range of 31-40 years old (84 respondents or 35\%), and for 41-50 years old, there were 38 respondents (15.84\%). Educational background showed that the majority of the employees have an Associate degree (D1, D2, and D3) 133 respondents $(55.41 \%) ; 88$ respondents (36.67\%) have a high school degree, and 38 respondents (7.92\%) have a Bachelor's degree (S1 and D4). In terms of length of work, the majority of the employees had been working for their employer for 3-8 years (155 respondents or $64.58 \%$ ); 48 respondents (20\%) had been there 9-14 years. The remaining 37 respondents $(15.42 \%)$ had been with their employer for less than 3 years. Based on the department, most of the respondents $(165$ respondents or $68.75 \%$ ) were in housekeeping, and the other 75 respondents $(31.25 \%)$ were in the front office department.

Table 1 . The Test of Validity and Reliability

\begin{tabular}{|l|c|c|c|c|}
\hline \multicolumn{1}{|c|}{ Indicator of Variables } & CA & rho_A & CR & AVE \\
\hline $\begin{array}{l}\text { My - feelings of ownership as } \\
\text { "I" - (X1) }\end{array}$ & 0.815 & 0.838 & 0.892 & 0.734 \\
\hline $\begin{array}{l}\text { Ours - feelings of ownership as } \\
\text { "us" - (X2) }\end{array}$ & 0.714 & 0.712 & 0.820 & 0.533 \\
\hline $\begin{array}{l}\text { Mine - feelings of ownership in } \\
\text { general - (X3) }\end{array}$ & 0.649 & 0.653 & 0.811 & 0.589 \\
\hline The job itself - (Y11) & 0.537 & 1.032 & 0.774 & 0.644 \\
\hline Pay - (Y12) & 0.802 & 0.818 & 0.884 & 0.717 \\
\hline Supervision - (Y13) & 0.870 & 0.886 & 0.911 & 0.718 \\
\hline Co-worker - (Y14) & 0.676 & 0.677 & 0.821 & 0.605 \\
\hline Altruism (helping others) - (Y21) & 0.795 & 0.805 & 0.907 & 0.829 \\
\hline Conscientiousness - (Y22) & 0.746 & 0.768 & 0.860 & 0.678 \\
\hline Sportsmanship - (Y23) & 0.773 & 0.774 & 0.868 & 0.687 \\
\hline Courtesy - (Y24) & 0.847 & 0.851 & 0.908 & 0.767 \\
\hline Civic virtue - (Y25) & 0.674 & 0.708 & 0.858 & 0.751 \\
\hline
\end{tabular}

Table 2. The Outer Loading

Value Indicator of Research Variable

\begin{tabular}{|l|l|c|}
\hline \multicolumn{1}{|c|}{ Variable } & \multicolumn{1}{|c|}{ Indicator } & Outer Loading \\
\hline \multirow{4}{*}{$\begin{array}{l}\text { Psychological } \\
\text { ownership } \\
\left(\mathrm{X}_{1}\right)\end{array}$} & $\begin{array}{l}\text { "My" is a feeling of } \\
\text { ownership as "I" }\left(\mathrm{X}_{1.1}\right)\end{array}$ & 0.883 \\
\cline { 2 - 3 } & $\begin{array}{l}\text { "Ours" is a feeling of } \\
\text { ownership as "we" }\left(\mathrm{X}_{1.2}\right)\end{array}$ & 0.866 \\
\cline { 2 - 3 } & $\begin{array}{l}\text { "Mine" is a general feeling } \\
\text { of ownership }\left(\mathrm{X}_{1.3}\right)\end{array}$ & 0.831 \\
\hline \multirow{2}{*}{$\begin{array}{l}\text { Job } \\
\text { satisfaction } \\
\left(\mathrm{Y}_{1}\right)\end{array}$} & The work itself $\left(\mathrm{Y}_{1.1}\right)$ & 0.635 \\
\cline { 2 - 3 } & Pay $\left(\mathrm{Y}_{1.2}\right)$ & 0.809 \\
\cline { 2 - 3 } & Supervision $\left(\mathrm{Y}_{1.3}\right)$ & 0.919 \\
\cline { 2 - 3 } $\begin{array}{l}\text { Organizationa } \\
\text { l citizenship } \\
\text { behavior }\left(\mathrm{Y}_{2}\right)\end{array}$ & Co-Worker $\left(\mathrm{Y}_{1.4}\right)$ & 0.771 \\
\cline { 2 - 3 } & Conscientiousness $\left(\mathrm{Y}_{1.2}\right)$ & 0.636 \\
\cline { 2 - 3 } & Sportsmanship $\left(\mathrm{Y}_{1.3}\right)$ & 0.857 \\
\cline { 2 - 3 } & Courtesy $\left(\mathrm{Y}_{1.4}\right)$ & 0.886 \\
\cline { 2 - 3 } & Civic virtue $\left(\mathrm{Y}_{1.5}\right)$ & 0.828 \\
\hline
\end{tabular}

\section{RESULTS}

The validity and reliability test required a model feasibility test for every construct used. The analysis results show the validity and reliability test result upon the construct. Table 1 shows that the Cronbach's alpha values range from 0.6-0.70, so the assessment is considered to be reliable. The next assessment of data quality is by examining the rho_A. The variables are considered as reliable if the variance rho_A values are higher than $0.70(>0.70)$. This result of the data quality test shows that the variance of rho-A values are above 0.70; thus, they confirm the Cronbach's alpha values, which have already been considered as reliable. The data quality test also examines the values of composite reliability-they are considered reliable if the variance value is a minimum of 0.70 (Chin and Newsted, 1999; Ghozali and Latan, 2012). The result of the composite reliability calculation is higher than 0.70 , which means the model has met the composite criteria. Furthermore, the data that has been analyzed must be qualified to the convergent validity. It aims to test the instrument's validity specifically for the reflective indicator. The range of AVE values from 0.50 to 0.60 is considered as adequate (Ghozali and Latan, 2012). Therefore, it can be concluded that these values meet the convergent criteria. The convergent validity test is also measured based on the values of the loading factor $(\geq 0.50)$ from the construct indicator, as presented in Table 2 .

The result of the outer model test, which includes the convergent validity, rho_a, discriminant validity, composite reliability, Cronbach's alpha, and outer loading to assess the validity and reliability of the indicator in the outer model evaluation, shows that all those tests have met the criteria. Accordingly, the model qualifies for the several requirements of validity and reliability in the use of SmartPLS analysis; therefore, the model is confirmed to be valid and reliable. This research also uses a number of approaches to evaluate the structural model (inner model), which is the Q Square Predictive Relevance $\left(\mathrm{Q}^{2}\right)$ and Goodness of Fit $(\mathrm{GoF})$. The $Q^{2}$ predictive relevance test refers to formula is as follows.

$$
\left.\mathrm{Q}^{2}=1-\left(1-\mathrm{R}_{1}{ }^{2}\right)\left(1-\mathrm{R}_{2}{ }^{2}\right) \ldots \ldots \ldots . .1\right) \text {. Hair et al. (2006) }
$$

Based on the data of $\mathrm{R}$ square $\left(\mathrm{R}^{2}\right)$ in Table 3, the value of $Q^{2}$ predictive relevance can be calculated through the following formula. $\mathrm{Q}^{2}=1-(1-0.554)(1-0.341) . \mathrm{Q}^{2}=1-(0.446)(0.659)=\mathrm{Q}^{2}=0.70609\left(Q^{2}\right.$ predictive relevance is good). The calculation resulted in a $Q^{2}$ value of 0.70609 ; therefore, it can be interpreted that the model shows a very good level of prediction. From the result, it can be acknowledged that as much as $70.61 \%$ of the relations among analyzed variables in 
the model can be explained by the model thoroughly, while the rest, 29.39\%, are influenced by other variables that cannot be used in the research model. The GoF is an overall model developed by Ghozali and Latan (2012) and Hair et al. (2006) uses three criteria of GoF, where 0.10 is categorized as small, 0.25 as medium, and 0.36 as large.

Table 3. $\mathrm{R}^{2}$ endogenous Variable

\begin{tabular}{|l|c|c|}
\hline \multicolumn{1}{|c|}{ Variables } & $\begin{array}{c}\mathrm{R} \\
\text { Square }\end{array}$ & $\begin{array}{c}\text { R Square } \\
\text { Adjusted }\end{array}$ \\
\hline Job Satisfaction (Y1) & 0.554 & 0.552 \\
\hline Organizational Citizenship Behaviour (Y2) & 0.341 & 0.335 \\
\hline
\end{tabular}

Below is the assessment of GoF. GoF $=$ Vaverage AVE $\mathrm{x}$ average $\mathrm{R}^{2}=\sqrt{0.421} \times \mathrm{x} 0.447=\sqrt{ } 0.188=0.434$. The assessment result of the GoF research model shows the GoF value as 0.434 , thoroughly defines the accuracy of the assessment model very well because it falls into the large GoF category (>0.36). The hypothesis test related to the influence among variables using $\mathrm{PLS}_{3}$ analysis is presented in Table 4 as follows. Table 4 also shows the analysis results of the relationships between variables, showing that all relationships are confirmed to be significant. The analysis results are presented in the following Figure 1.

The hypothesis proves that PO is positive and significant effect toward the OCB, which means that hypothesis 1 (H1) is accepted. The path coefficient of effects shows a value of 0.390 , with a t-statistic of $4.574<1.96$ and a significance level (p-values) of 0.000. This result means that the higher the PO, the higher the OCB would be. The analysis results that JS affects the OCB positively and significantly, which means that hypothesis 2 (H2) is accepted. The test result shows the path coefficient as 0.232 , with a t-statistic value of $2.686>1.96$ (t-critical), and significance level (p-values) of 0.007 . Moreover, the analysis results in the positive and significant effect of PO toward JS, which means that hypothesis 3 (H3) is accepted. This result shows that there is a path coefficient of 0.744 with a t-statistic of $19.296(<1.96)$ and a level of significance (p-values) of 0.000. Accordingly, the hypothesis that states that PO positively and significantly affects the JS is supported.

\section{DISCUSSIONS}

PO is an individual psychological experience that occurs when an individual develops a sense of possessiveness towards a certain target that later becomes the foundation of the PO (Van Dyne and Pierce, 2004). If an employee perceives an object as theirs, then feelings of ownership of that object will become stronger (Caspi and Blau, 2011). Mann (1991) wrote, "What I own feels like a part of me." Feelings of ownership of such items are significant and have a strong psychological and behavioural impact. The goal is usually tangible, such as toys, homes, property, and others, but may also be intangible, including profits, ideas, and growth. Employees that have a high level of PO appear to be more satisfied with their jobs. The happiness or disappointment felt by workers is the product of a contrast of what they have earned from their jobs with their expectations for the job (O'Connor, 2018; Masum et al., 2016). Hope will be felt if the disparity or distance between the individual expectations is fairly low in comparison to what they really obtain from the job. On the other hand, frustration would be felt if there is a significant difference between their expectations and what they benefit from the work. Having strong PO could increase the JS felt by employees. According to Pierce et al. (2004) PO is a state in which individuals believe that some part belongs to them. The purpose or object of the PO may be materialistic (things, facilities), but it may also be non-materialistic, such as thoughts, creative arts, sounds, etc. (Pierce et al., 2004). Employees who perceive an organization's goal as their own goal appear to experience a higher degree of JS when performing their tasks.

PO represents the interaction between individuals and an entity (material or immaterial) when the objects have a close link with the individuals (Furby, 1978; Furby, 1991). Ownership plays a dominant role in the identity of someone and becomes part of their extended self (Belk, 1988). As Pierce et al. (2001) have pointed out, what has become the possession of individuals (mentally) has also become part of their extended self, in the form of an individual and a psychological sense of ownership. Extended self includes a person, thing or place that has a psychological influence on a part of someone's self (Ramos et al., 2014). PO represents one's own awareness, perception, and confidence in relation to the goal of ownership. This cognitive condition also involves an affective component or emotional sensation. It is said that the feelings of ownership generate happiness, which is also basically imbued with the feelings of competence and success. Moreover, when someone admits that their targets are theirs, or that they belong to a certain group of people, the affective component will be clear.

The findings of the study indicate that the OCB is influenced positively and substantially by PO. The lower the PO, the higher the OCB of the employee. A study conducted by Van Dyne and Pierce (2004) found that PO in an organization psychologically influences the employees in their job description to be willing to do extra work beyond their formal tasks. Ownership feelings towards an object can move a subject to act positively towards anything he/she has, cultivate self-efficacy and increase the sense of responsibility towards the organization. JS is individualistic, and according to current values, levels of satisfaction will vary. Ozturk (2010) notes that JS is a general attitude towards someone's job which considers the difference between the numbers of awards the employee earns and the number they think they should earn. Research shows that JS affects the OCB positively and substantially (Foote and Li-Ping Tang, 2008; Mohammad et al., 2011; Ozturk, 2010). This 
suggests that the more the workers are happy with the job and their working environment, the higher the OCB of workers would be (Mushtaq et al., 2014). Agrawal and Gautam (2020) underscorees that positive emotional and happy responses to an organization's assessment of the job, salary, promotion, supervision, and co-workers may voluntarily increase positive workplace behaviour. JS of workers also affects their ability to demonstrate OCB (Van Dyne and Pierce, 2004; Foote and LiPing Tang, 2008). If the employees are very happy with the aspects of work (e.g. work itself, salary, promotion, supervision, and help for coworkers), then the employees will be willing to do additional work (Hayati and Caniago, 2012). This study examined the attitude effect (JS) and personality traits (PO) against OCB. Theoretically, some previous studies suggest that the predictors of OCB are JS and organizational engagement as indicators of the attitudes of the employees. Yee, Wong Sek Khin, and Ismail (2018) explain the PO's determinants include some of an employee's personal characteristics, such as feelings of ownership in mind and practice, motivation, good sense of ownership, self-efficacy, belonging and self-identity.

Therefore, personal characteristics have a stronger influence in the cultivation of extra-role behavior (OCB) than attitude (Yee et al., 2018). It also confirms that PO's direct effects in creating OCB are stronger with JS. This finding clarifies that in OCB of workers, the personal construct has a greater impact than the attitude construct. Therefore, when hiring new staff, the hotel management should consider evaluating personality characteristics for appropriate employee job placement. Ivancevich and Hoon (2007) clarify that human resources management needs to have an attitude towards hiring workers according to the organization's needs in order to strengthen the person-organizational match. Recruiting the right staff requires a strategy of choosing the highly skilled and best suited employees for the organization (Belcourt et al., 2008).

\section{CONCLUSION AND LIMITATIONS}

A good sense of ownership by employees is a factor that can increase JS. When workers feel satisfied, they may feel more empowered and thus able to maintain emotional feelings of ownership towards the organization. In fact, workers who feel happy with their work appear to exhibit activities that go beyond their job description (Aldrin and Yunanto, 2019; Sendjaya et al., 2019). Moreover, PO plays a central role in increasing OCB, and is the primary determinant. Yee et al. (2018) stressed the PO's determinants include a variety of employee personality traits, including a feeling of belonging in thoughts and acts, a driven feeling, a clear sense of ownership, self-efficacy, belonging and self-identity.

The findings of this study suggest that such personal characteristics (Yee et al., 2018) have a greater impact on attitudes toward extra-role behaviour (OCB). The study results also indicate that PO significantly affects OCB. However, these results clarify that the personality trait (psychological ownership) has a stronger effect on improving OCB of employees than the attitude (job satisfaction) has. This study has limitations in that only four-star hotels were included. In addition, factors of consideration in the hospitality industry continue to shift due to other circumstances. Furthermore, this study is cross-sectional, and longitudinal work is considered necessary to be able to describe the phenomenon in greater detail. There are some recommendations to hotels as well as to future researchers.

Management of a hotel is required to control OCB's primary determinant, which is PO, by attempting to improve feelings of ownership in employees towards the organization. One suggested goal is to foster personal feelings of ownership of workers, so they feel more engaged and form bonds within the company.

Therefore, when helping each other, the hotel management is expected to create some clear rules relating to the primary tasks and responsibilities as a guide for the employees. An integrated model of OCB determinants can be established by analysing the elements of organizational commitment in the model.

\section{Acknowledgment}

The authors are grateful to Udayana University (Badung, Bali) for the financial support granted to this research project and collaboration with Universiti Teknologi Mara Malaysia (Sarawak branch), Sekolah Tinggi Ilmu Ekonomi Samarinda, Mulawarman University, and also Pace University (New York).

\section{Conflict of interest}

We declare no conflicts of interest at a later date and this study is aimed at various parties.

\section{REFERENCES}

Afaq, A.K., Sharif, N., \& Ahmad, N. (2017). Factors Influencing Students' Career Choices: Empirical Evidence from Business Students. Journal of Southeast Asian Research, 1-15. https://doi.org/10.5171/2017.718849

Aftab, H. (2012). A Study of Job Satisfaction and IT's Impact on the Performance in the Banking Industry of Pakistan. International Journal of Business and Social Science, 3(19), 174-180. https://doi.org/10.30845/ijbss

Agrawal, P., \& Gautam, O. (2020). The Effects of Leaders' Behavior on Job Satisfaction, Organizational Citizenship Behavior, Deviant Behavior, and Job Performance of Employees. In Advances in Human Resources Management and Organizational Development (pp. 100-113). https://doi.org/10.1177/1523422320927295

Aldrin, N., \& Yunanto, K.T. (2019). Job Satisfaction as a Mediator for the Influence of Transformational Leadership and Organizational Culture on Organizational Citizenship Behavior. The Open Psychology Journal, 12(1), 126-134. https://doi.org/10.2174/1874350101912010126

Akter, M, Alim, M.A, Shabbir, R., Ali, M.B, Teck-Weng, J., \& Kasuma, J. (2020). The mediating effects of place satisfaction and support for community: An evaluation of the performance of small and medium tourism enterprises in Bangladesh. Asian Journal of Business and Accounting, 13(2), 27-48. https://doi.org/10.22452/ajba.vol13no2.2

Arusteu, C. (2013). Employees' organizational commitment challenges-A hotel industry perspective. Management Dynamics in the Knowledge Economy, 1(3), 497-520. URL: http://www.managementdynamics.ro/index.php/journal/article/view/16

Asha, C.S., \& Jyothi, P. (2013). Internal Branding: A Determining Element of Organizational Citizenship Behavior. Journal of Contemporary Management Research, 7(1), 37-57. https://doi.org/10.1016/j.sbspro.2014.09.127 
Bambale, A.J. (2013). The mediating effect of psychological ownership on the relationship between servant leadership and organizational citizenship behaviors in Kano, Nigeria. Universiti Utara Malaysia. URL: https://core.ac.uk/display/268139599? utm_source=pdf\&utm_medium=banner\&utm_campaign=pdf-decoration-v1

Barney, J. (1991). Firm Resources and Sustained Competitive Advantage. Journal of Management, 17(1), 99-120. https://doi.org/ $10.1177 / 014920639101700108$

Belcourt, M., Bohlander, G., \& Snell, S. (2008). Managing human resourcesm, $5^{\text {th }}$ Canadian Edition. Toronto: Nelson.

Belk, R.W. (1988). Possessions and the Extended Self. Journal of Consumer Research, 15(2), 139. https://doi.org/10.1086/209154

Caspi, A., \& Blau, I. (2011). Collaboration and psychological ownership: How does the tension between the two influence perceived learning? Social Psychology of Education, 14(2), 283-298. https://doi.org/10.1007/s11218-010-9141-z

Chiaburu, D.S., Oh, I.S., Berry, C.M., Li, N., \& Gardner, R.G. (2011). The five-factor model of personality traits and organizational citizenship behaviors: A meta-analysis. Journal of Applied Psychology, 96(6), 1140-1166. https://doi.org/10.1037/a0024004

Choi, S., Hwang, C., \& Kwon, D. (2019). On the Effect of Dispersed Leadership of Vocational Training Teachers on Job Satisfaction Through Organization Citizenship Behavior and Teacher Empowerment. Journal of the Korea Society of Digital Industry and Information Management, 15(1), 109-122. https://doi.org/10.17662/ksdim.2019.15.1.109

Chin, W.W., \& Newsted, P.R. (1999). 'Structural Equation Modeling Analysis with Small Sample Using Partial Least Squares'. In Statistical Strategies for Small Sample Research, ed. Hoyle, R. H. Sage Publication, Inc., Thousand Oaks - California, pp. $307-341$. https://doi.org/10.1177/0047287515569779

Cohen, A., \& Vigoda, E. (2000). Do Good Citizens Make Good Organizational Citizens? Administration \& Society, 32(5), 596-624. https://doi.org/10.1177/00953990022019597

Darma, D.C, Maria, S., Kasuma, J., \& Lestari, D. (2020). Factors involved in the number of tourist visits in the Muara Badak, Indonesia. Religación. Revista De Ciencias Sociales Y Humanidades, 5(24), 142-151. https://doi.org/10.46652/rgn.v5i24.623

Foote, D.A., \& Li-Ping Tang, T. (2008). Job satisfaction and organizational citizenship behavior (OCB). Management Decision, 46(6), 933-947. https://doi.org/10.1108/00251740810882680

Furby, L. (1978). Possession In Humans: An Exploratory Study Of Its Meaning And Motivation. Social Behavior and Personality: An International Journal, 6(1), 49-65. https://doi.org/10.2224/sbp.1978.6.1.49

Furby, L. (1991). Understanding the psychology of possession and ownership: A personal memoir and an appraisal of our progress. Journal of Social Behavior and Personality, 6(6), 457. proquest.com/openview/1819046

Ghozali, I., \& Latan, H. (2012). Partial Least Square: Konsep, Teknik dan Aplikasi Smart PLS 2.0. Semarang: Badan Penerbit Universitas Diponegoro.

Hair, J.F., Black, W.C., Babin, B.J., Anderson, R.E., \& Tatham, R.L. (2006). Multivariate data analysis (Vol. 6). Upper Saddle River, N.J: Pearson Prentice Hall.

Hakim, A.L., \& Sutrisno, S. (2018). The Effect of Work Stress on Turnover Intention with Work Satisfaction and Commitment as Intervening Variable (Study at PT. Infomedia Solusi Humanika, Malang). European Journal of Business and Management, 10(12), 85-95. https://www.iiste.org/Journals/index.php/EJBM/article/view/42153

Hallin, C.A., \& Marnburg, E. (2008). Knowledge management in the hospitality industry: A review of empirical research. Tourism Management, 29(2), 366-381. https://doi.org/10.1016/j.tourman.2007.02.019

Hayati, K., \& Caniago, I. (2012). Islamic Work Ethic: The Role of Intrinsic Motivation, Job Satisfaction, Organizational Commitment and Job Performance. Procedia - Social and Behavioral Sciences, 65, 1102-1106. https://doi.org/10.1016/j.sbspro.2014.05.148

Ileri, H., \& Soylu, Y. (2012). The Measurement Of The Effect Of Person-Job Fit And Person-Organization Fit On Burnout-A Selcuk University Meram Medical Faculty Hospital Example. International Journal of Arts \& Sciences, 5(2), 447. proquest.com/docview/6724

Ivancevich, J.M., \& Lee, S.M. (2007). Human Resource Management in Asia. McGraw-Hill, Singapore.

Kamri, T., Kasuma, J., Kutok, J., \& Darma, D.C. (2020). Do Tourists Willing to Pay for the Value of Environmental Conservation? A Case of Annah Rais Longhouse and Hot Springs. Journal of Tourism Management Research, 7(2), 218-228. https://doi.org/ 10.18488/journal.31.2020.72.218.228

Katz, D. (1964). The motivational basis of organizational behavior. Behavioral Science, 9(2), 131-146. https://doi.org/ $10.1002 / \mathrm{bs} .3830090206$

Khalid, K., Salim, H.M., \& Loke, S.P. (2011). The impact of rewards and motivation on job satisfaction in water utility industry. International Conference on Financial Management and Economics, 11(2), 35-41. http://www.ipedr.com/vol11/7-R00013.pdf

Kim, S. (2006). Public service motivation and organizational citizenship behavior in Korea. International Journal of Manpower, 27(8), 722-740. https://doi.org/10.1108/01437720610713521

Klein, K.J., \& Kozlowski, S.W.J. (2000). From Micro to Meso: Critical Steps in Conceptualizing and Conducting Multilevel Research. Organizational Research Methods, 3(3), 211-236. https://doi.org/10.1177/109442810033001

Kumar, K., Bakhshi, A., \& Rani, E. (2009). Linking the Big Five personality domains to Organizational citizenship behavior. International Journal of Psychological Studies, 1(2), 73-81. https://doi.org/10.5539/ijps.v1n2p73

Mann, D.W. (1991). Ownership: A pathography of the self. British Journal of Medical Psychology, 64(3), 211-223. https://doi.org/ 10.1111/j.2044-8341.1991.tb01660.x

Masum, A.K., Azad, M.A., Hoque, K.E., Beh, L.S., Wanke, P., \& Arslan, Ö. (2016). Job satisfaction and intention to quit: an empirical analysis of nurses in Turkey. PeerJ, 4, e1896. https://doi.org/10.7717/peerj.1896

Mohammad, J., Quoquab, Habib, F., \& Alias, M.A. (2011). Job Satisfaction and Organisational Citizenship Behaviour: an Empirical Study at Higher Learning Institutions. Asian Academy of Management Journal, 16(2), 49-165. http://web.usm.my/aamj/16.2.2011/AAMJ_16.2.7.pdf

Murphy, G., Athanasou, J., \& King, N. (2002). Job satisfaction and organizational citizenship behaviour. Journal of Managerial Psychology, 17(4), 287-297. https://doi.org/10.1108/02683940210428092

Mushtaq, K., Ahmed, M., \& Warraich, S. (2014). A study on job satisfaction, motivation and organizational citizenship behavior. International Journal of Management Sciences and Business Research, 3(11), 1-12. ssrn.com/abstract=2731023

Mustafa, M., Martin, L., \& Hughes, M. (2016). Psychological Ownership, Job Satisfaction, and Middle Manager Entrepreneurial Behavior. Journal of Leadership \& Organizational Studies, 23(3), 272-287. https://doi.org/10.1177/1548051815627360

Mustafa, M., Ramos, H.M., \& Man, T.W.Y. (2015). Linking psychological ownership to employee extra-role behaviours in small overseas Chinese family businesses. Journal of Entrepreneurship in Emerging Economies, 7(2), 129-147. https://doi.org/10.1108/JEEE-11-2014-0041

Noermijati, N., \& Primasari, D. (2015). The effect of job stress and job motivation on employee s' performance through job satisfaction (A study at PT. Jasa Marga (Persero) Tbk. Surabaya - Gempol branch). Journal of Economics, Business \& Accountancy Ventura, 18(2), 231-240. https://doi.org/10.14414/jebav.v18i2.450 
Nurak, L., \& Riana, G. (2017). Examine the Effect of Organizational Justice on Job Satisfaction and employee performance. Journal of Management and Marketing Review, 2(3), 30-37. https://doi.org/10.35609/jmmr.2017.2.3(4)

O'Connor, J. (2018). The Impact of Job Satisfaction on the Turnover Intent of Executive Level Central Office Administrators in Texas Public School Districts: A Quantitative Study of Work Related Constructs. Education Sciences, 8(2), 69. https://doi.org/10.3390/educsci8020069

Organ, D.W. (1997). Organizational Citizenship Behavior: It's Construct Clean-Up Time. Human Performance, 10(2), 85-97. https://doi.org/10.1207/s15327043hup1002_2

Organ, D.W., Podsakoff, P.M., \& MacKenzie, S.B. (2005). Organizational citizenship behavior: Its nature, antecedents, and consequences. Sage Publications.

Organ, D.W., \& Ryan, K. (1995). A meta-analytic review of attitudinal and dispositional predictors of organizational citizenship behavior. Personnel Psychology, 48(4), 775-802. https://doi.org/10.1111/j.1744-6570.1995.tb01781.x

Ozturk, F. (2010). Determinants of organizational citizenship behavior among knowledge workers: The role of job characteristics, job satisfaction, and organizational commitment. Graduate Thesis, Master-Degree Program in Business Administration.

Pan, X.F., Qin, Q., \& Gao, F. (2014). Psychological ownership, organization-based self-esteem and positive organizational behaviors. Chinese Management Studies, 8(1), 127-148. https://doi.org/10.1108/CMS-04-2014-0088

Pierce, J.L., Kostova, T., \& Dirks, K.T. (2001). Toward a Theory of Psychological Ownership in Organizations. Academy of Management Review, 26(2), 298-310. https://doi.org/10.5465/amr.2001.4378028

Pierce, J.L., O'driscoll, M.P., \& Coghlan, A. (2004). Work Environment Structure and Psychological Ownership: The Mediating Effects of Control. The Journal of Social Psychology, 144(5), 507-534. https://doi.org/10.3200/SOCP.144.5.507-534

Podsakoff, N.P., Whiting, S.W., Podsakoff, P.M., \& Blume, B.D. (2009). Individual-and organizational-level consequences of organizational citizenship behaviors: A meta-analysis. Journal of Applied Psychology, 94(1), 122-141. https://doi.org/10.1037/a0013079

Podsakoff, P.M., MacKenzie, S.B., Lee, J.Y., \& Podsakoff, N.P. (2003). Common method biases in behavioral research: A critical review of the literature and recommended remedies. Journal of Applied Psychology, 88(5), 879-903. https://doi.org/10.1037/0021-9010.88.5.879

Podsakoff, P.M., MacKenzie, S.B., Paine, J.B., \& Bachrach, D.G. (2000). Organizational Citizenship Behaviors: A Critical Review of the Theoretical and Empirical Literature and Suggestions for Future Research. Journal of Management, 26(3), 513-563. https://doi.org/10.1016/S0149-2063(00)00047-7

Rahmawati, R., Oktora, K., Ratnasari, S.L., Ramadania, R., \& Darma, D.C. (2021). Is it true that lombok deserves to be a halal tourist destination in the world? A perception of domestic tourists. GeoJournal of Tourism and Geosites, 34(1), 94-101. https://doi.org/10.30892/gtg.34113-624

Ramos, H.M., Man, T.W.Y., Mustafa, M., \& Ng, Z.Z. (2014). Psychological ownership in small family firms: Family and non-family employees' work attitudes and behaviours. Journal of Family Business Strategy, 5(3), 300-311. https://doi.org/10.1016/j.jfbs.2014.04.001

Ratnasari, S., Susanti, E., Ismanto, W., Tanjung, R., Darma, D.C., \& Sutjahjo, G. (2020). An Experience of Tourism Development: How is the Strategy?. Journal of Environmental Management and Tourism, 11(7), 1877-1886. https://doi.org/10.14505//jemt.v11.7(47).26

Riana, I.G., Aristana, I.N., Rihayana, I.G., Wiagustini, N.L.P., \& Abbas, E.W. (2020). High-performance work system in moderating entrepreneurial leadership, employee creativity and knowledge sharing. Polish Journal of Management Studies, 21(1), 328-341. https://doi.org/10.17512/pjms.2020.21.1.24

Riana, I.G., Dwijayanti, I., Rihayana, I.G., \& Wiagustini, N.L.P. (2018). Managing Work Family Conflict and Work Stress through Job Satisfaction and Its Impact on Employee Performance. Jurnal Teknik Industri, 20(2), 127-134. https://doi.org/10.9744/jti.20.2.127-134

Robbins, S.P., \& Judge, T.A. (2015). Perilaku Organisasi (Organizational Behavior 16th edition). Jakarta: McGraw Hill Dan Salemba Empat.

Samancioglu, M., Baglibel, M., \& Erwin, B.J. (2020). Effects of Distributed Leadership on Teachers' Job Satisfaction, Organizational Commitment and Organizational Citizenship. Pedagogical Research, 5(2), em0052. https://doi.org/10.29333/pr/6439

Sendjaya, S., Pekerti, A.A., Cooper, B.K., \& Zhu, C.J. (2019). Fostering Organisational Citizenship Behaviour in Asia: The Mediating Roles of Trust and Job Satisfaction. In Leading for High Performance in Asia (pp. 1-18). Springer Singapore.

Shokrkon, H., \& Naami, A. (2008). The relationship of job satisfaction with organizational citizenship behavior and job performance in Ahvaz factory workers. Journal of Education \& Psychology, 3(2), 39-52. https://www.sid.ir/en/journal/ViewPaper.aspx?ID=196085

Sloat, K.C.M. (1999). Organizational citizenship. Professional Safety, 44(4), 20. URL: proquest.com/docview/200332744

Smith, C.A., Organ, D.W., \& Near, J.P. (1983). Organizational citizenship behavior: Its nature and antecedents. Journal of Applied Psychology, 68(4), 653-663. https://doi.org/10.1037/0021-9010.68.4.653

Spector, P.E. (1985). Measurement of human service staff satisfaction: Development of the Job Satisfaction Survey. American Journal of Community Psychology, 13(6), 693-713. https://doi.org/10.1007/BF00929796

Suharto, R.B., Roy, J., \& Darma, D.C. (2019). Degree of potential and development strategy of tourism objects. International Journal of Scientific and Technology Research, 8(9), 2343-2347. http://www.ijstr.org/final-print/sep2019/Degree-Of-Potential-AndDevelopment-Strategy-Of-Tourism-Objects.pdf

Tsai, Y., \& Wu, S.W. (2010). The relationships between organisational citizenship behaviour, job satisfaction and turnover intention. Journal of Clinical Nursing, 19(23-24), 3564-3574. https://doi.org/10.1111/j.1365-2702.2010.03375.x

Van Dyne, L., \& Pierce, J.L. (2004). Psychological ownership and feelings of possession: three field studies predicting employee attitudes and organizational citizenship behavior. Journal of Organizational Behavior, 25(4), 439-459. https://doi.org/10.1002/job.249

Vandewalle, D., Van Dyne, L., \& Kostova, T. (1995). Psychological Ownership: An Empirical Examination of its Consequences. Group \& Organization Management, 20(2), 210-226. https://doi.org/10.1177\%2F1059601195202008

Yee, C.M., Wong Sek Khin, E., \& Ismail, K. (2018). Determinants of employees' psychological ownership on budgetary slack. Audit Financiar, 16(149), 122-130. https://doi.org/10.20869/AUDITF/2018/149/004

Yoon, M.H., \& Suh, J. (2003). Organizational citizenship behaviors and service quality as external effectiveness of contact employees. Journal of Business Research, 56(8), 597-611. https://doi.org/10.1016/S0148-2963(01)00290-9

Zeinabadi, H. (2010). Job satisfaction and organizational commitment as antecedents of Organizational Citizenship Behavior (OCB) of teachers. Procedia - Social and Behavioral Sciences, 5, 998-1003. https://doi.org/10.1016/j.sbspro.2010.07.225

Zhao, H., Peng, Z., \& Chen, H.K. (2014). Compulsory citizenship behavior and organizational citizenship behavior: The role of organizational identification and perceived interactional justice. The Journal of Psychology, 148(2), 177-196. https://doi.org/ $10.1080 / 00223980.2013 .768591$

Zheng, X., Diaz, I., Tang, N., \& Tang, K. (2014). Job insecurity and job satisfaction: The interactively moderating effects of optimism and person-supervisor deep-level similarity. Career Development International. https://doi.org/10.1108/CDI-10-2013-0121 